\title{
GREGORY SKOVORODA: THE 18th CENTURY UKRAINIAN WRITER AND PHILOSOPHER ${ }^{1}$
}

\section{Abstract:}

The article discusses the work and teachings of Gregory Savich Skovoroda (1722-94), a prominent Ukrainian writer, philosopher, teacher and educator. His doctrine of "three worlds" still causes very different interpretations in academic studies. Skovoroda was a poet who wrote spiritual poetry. He wrote poems, particularly various sorts of the songs, treatises, parables, dialogues, fables and made translations. Skovoroda became widely known as a writer even during his life time. However, interest in his philosophical works developed only many years after his death. Gregory Skovoroda is one of the most remarkable thinkers in the history of Slavic cultures and literature.

\section{Keywords:}

Gregory Skovoroda, Cyril and Methodius heritage, Ukrainian literature.

АННОТАЦИЯ: Л.Л. ЩАВИНСКАЯ. «ГРИГОРИЙ СКОВОРОДА - УКРАИНСКИЙ ПИСАТЕЛЬ И ФИЛОСОФ XVIII В.».

В статье рассматривается деятельность и учение Григория Саввича Сковороды (1722-94) - выдающегося украинского писателя, философа и педагога-просветителя. Его учение о «трех мирах» до сих пор вызывает весьма различные толкования в научных кругах. Сковорода был поэтом, писавшим духовные стихи. Он сочинял стихотворные произведения, прежде всего различного рода песни, писал трактаты, притчи, диалоги, басни, делал переводы. Еще при жизни писатель Сковорода стал широко известен. Но интерес к его философским произведениям стал возрастать лишь через много лет после кончины их автора. Сковорода является одним из самых замечательных мыслителей в истории славянских культур и литератур.

\section{Ключевые слова:}

Григорий Сковорода, кирилло-мефодиевское наследие, украинская литература, философия.

C regory Skovoroda (1722-94) is an outstanding Ukrainian writer, phiJlosopher and educator who created the original doctrine of the "three worlds." He was born into a Cossack family in the Poltava region. With a break he studied at the Kievo-Mogila Academy, where St George of Konis was one of his teachers. He sang in the court choir of the Russian Empress Elizabeth Petrovna, traveled as part of her mission to the Austrian Empire, where he stayed for more than two years, learning about the local culture and science. Upon returning to

\footnotetext{
1 The work was carried out with the financial support of the RFBR (grant № 18-512-76004).
} 
his homeland, he taught at the Pereyaslavl Collegium, served as a private tutor, composed many spiritual songs that already made him famous among the people. For several years in the 1760 s, Skovoroda taught intermittently at Kharkov College and, after a series of conflicts with the church authorities, finally moved on to the position of a wandering sage: "the Elder." During this period, he created the major part of his works, his own philosophical doctrine crystallized, based on the concepts of "macrocosm," "microcosm," the "world of symbols" and two "natures." Skovoroda interpreted the Bible as a deeply symbolic book, and this biblical study deserves special attention, because only then is it possible to correctly understand everything he wrote.

The diversity of genres in Skovoroda's works was largely determined by the recipients for whom they were created. He composed poetry, particularly various sorts of songs, wrote treatises, parables, dialogues, fables, made translations, and the body of his epistolary works is significant. His satirical song, "Every city has a temper and a right," became widely known. It was derided by landowners, usurers and merchants. Later on it was put to music and eagerly performed by Kobzar singers.

The main language of Skovoroda's writings was the book language of that time, cultivated, in particular, at the Kievo-Mogila Academy, which included ma-

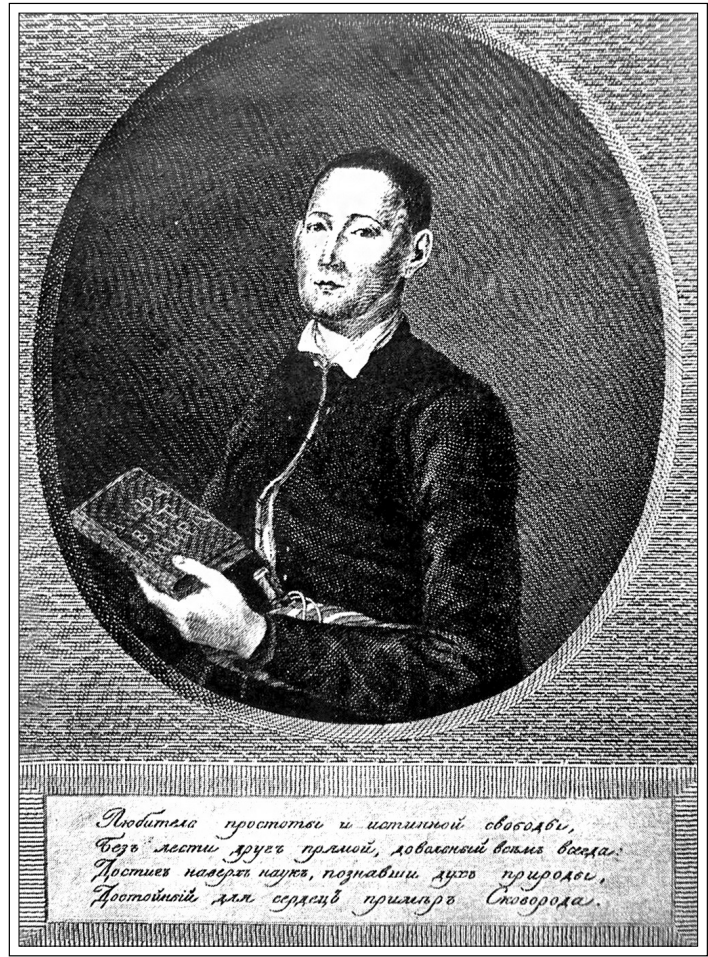

Gregory Skovoroda, engraving of the 19 th century ny Church Slavisms. Some of his works were created in Latin and Greek, which he knew. The most detailed and accurate information about the beginning of Skovoroda's main literary activity was left by his beloved student and friend, M.I. Kovalinsky, who wrote about Skovoroda's desire for solitude: "Skovoroda, prompted by the spirit, withdrew into deep solitude. Near Kharkov there is a place called Guzhvinsky, belonging to landowners by the name of Zemborsky, whom he loved for their kindness. It is covered with a gloomy forest, in the middle of which was an apiary with one hut. Here Gregory settled, hiding from the rumors of life and the slander of the clergy. Indulging in free reflection, and his peace of mind protected by silence, dispassion and the absence of worldly vani- 
ties, he wrote his first work here in the form of a book called by him Narcissus, or: Know Yourself. His earlier, previously written small works were only fragmentary, in verse and prose. Continuing his life as a recluse there, he wrote another work entitled: The book of Ashan' on the knowledge of himself, which he attributed to his friend. Kovalinsky who had known Skovoroda very closely for many years, also offered a very important description of his inner state: "Curiosity, settling in the heart of Skovoroda, brought him the well-being possible for the earth-born. Free from the bonds of all compulsion, vanity, temptation, care, he found all his desires fulfilled in the insignificance thereof. Engaged in reducing his natural wants and not in their propagation, he tasted pleasures incomparable to those of the fortunate. When the sun, burning countless candles on the woven emerald shroud, offered his meal with a generous hand to the senses, then he, accepting a cup of amusements, not dissolved by any sorrows of life, no passionate sighs, no vain distractions, and tasting the delight of high mindedness, in complete peace of complacency, used to say: "Thanks be to the all-blessed God that he made the necessary easy, and the difficult unnecessary!"

Skovoroda did not care much about the fate of his creations; at the end of his life he even wrote that "they would have disappeared long ago for me." In these years he called himself "the Elder, a teacher of the law of God Gregory Varsava Skovoroda" and asked: "What does Varsava mean? Var is a Jewish son; Sava is the sirs of the world. So Var - Ivan is the son of a dove; Var - Sava - the son of the world, i.e., the son of Sava." Thus, the external and internal appearance of Skovoroda can be described by his own definitions of "elder," "teacher of the law of God," "son of the world," which are very important for a correct understanding of the evolution of the philo-

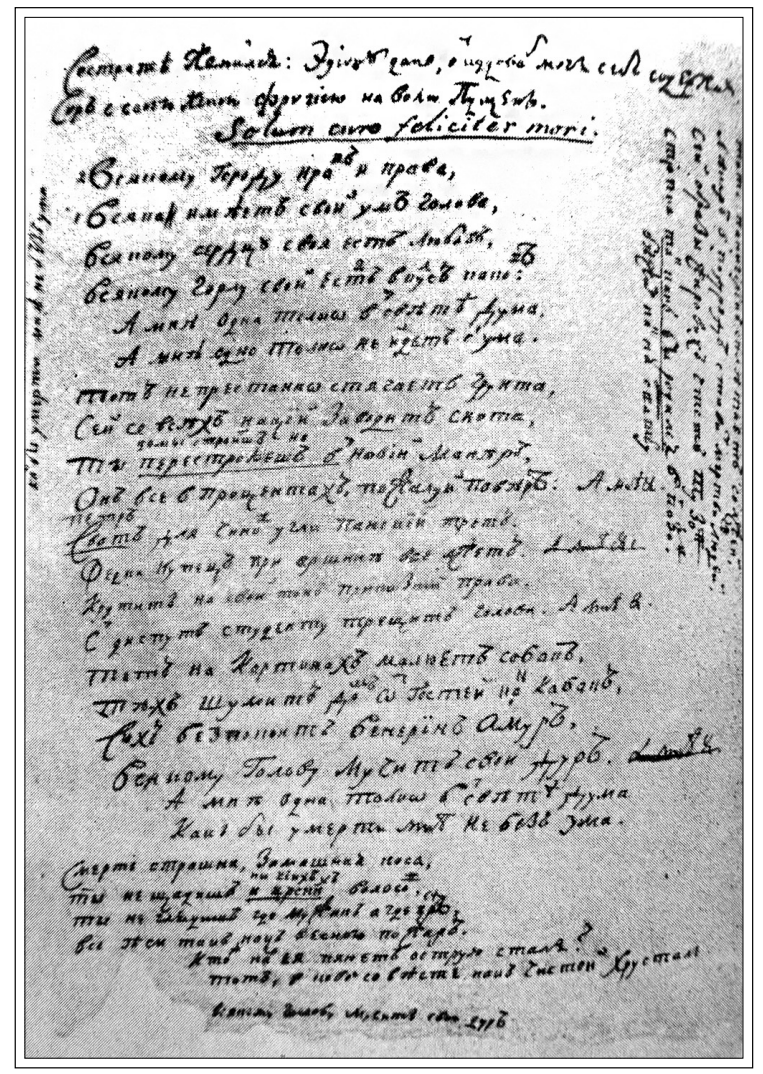

The handwritten text of the song by Gregory Skovoroda "Every city has a character and law." Kiev, Institute of Literature named after T.G. Shevchenko of the National Academy of Sciences of Ukraine. F. 86 , No. 24, L. 80 
sophical and theological and general life views of this philosopher. In contrast to the spiritual songs (cantos) of Skovoroda, which were widely disseminated among the people during the life of their author through rewriting, and more often due to the singing of wandering kobzars and lyrists, his first prose works began to be printed only after his death. They attracted the attention of prominent people from enlightened society only in the middle and second half of the 19th century. Moreover, by that time much of what he had written, but which remained in the manuscript form, had been lost.

Even during Skovoroda's lifetime, some manuscripts of his prose works were distributed among his not so numerous admirers, to whom we owe their preservation. The first attempts to collect Skovoroda's works were mainly made by Kovalinsky, whom the philosopher frankly informed that he "didn't give out autographs, but also distributed autographs, made gifts of them, squandered them" and even "burned" them in bitterness. In total, according to Skovoroda himself, the number of his creations was as follows:

“1) Narcissus, or: Know Yourself.

2) Symphony: rivers - I will keep my ways.

3) Symphony: Don't hang it.

4) Illiterate Marco.

5) Alphabet of the world: on nature.

6) Conversation 'Ring.'

7) Ancient world.

8) Lot's wife.

9) The battle of the Archangel Michael with Satan.

10) Icon of Alcibiades.

11) Conversation I. Zion.

12) Conversation II. Zion.

13) Conversation III. Two.

14) Dialogue: Soul and immortal Spirit.

15) Grateful Herod.

15a) Poor Lark.

16) On Christian good morality, or catechism.

17) Ashan', about knowing yourself.

Translations:

1) About old age (Cicero).

2) About God's justice ...

3) About death ...

4) About protection from debts ... 
5) About peace of mind ...

6) About lust for wealth ...

7) On solitude ... (Sidronia)."

Kovalinsky's final words about the works of the writer and philosopher are very important. Cited by him in his own handwritten essay, The Life of Gregory Skovoroda: "In addition to the works and their translations, many in Russian, Latin, Hellenic, his letters are very instructive, written to a friend and others; many poems and other works, a collection of which is partly kept by his friend. Since he wrote for his country, he sometimes used Little Russian dialects and spelling used in pronunciation of Little Russian: he always loved his natural language and rarely forced himself to express himself in a foreign language; he preferred Hellenic to all other foreign languages."

To date, there is a great deal written in many languages of the world devoted to the life and work of Skovoroda. Analysis of it allows us to make a convincing case that much of his legacy has received and continues to receive very different, sometimes completely contradictory evaluations. Researchers mostly agree, perhaps, on one thing: Gregory Skovoroda was one of the most remarkable thinkers in the history of Slavic cultures and literature, the undoubted and absolute pride of Eastern Slavia, "the peak of Old Ukrainian culture."

Translated by Igor Kaliganov

\section{WORKS}

Skovoroda H. Povna akademichna zbirka tvoriv. Kharkiv-Edmonton-Toronto, 2011.

\section{BIBLIOGRAPHY}

Chyzhev''kyi D. Filosofiia H.S. Skovorody. Warsaw, 1934.

Sofronova L.A. Tri mira Grigoriia Skovorody. Moscow, 2002.

Ushkalov L. Lovytva nevlovnoho ptakha: zhytia Hryhoriia Skovorody. Kiev, 2017.

\section{ILLUSTRATIONS}

1. A portrait of Gregory Skovoroda. Unknown artist, the end of the 18th century - beginning of the 19th century.

2. Gregory Skovoroda, engraving from the 19th century.

3. Personal belongings of Gregory Skovoroda. The National Literary and Memorial Museum of G.S. Skovoroda.

4. The handwritten text of the song by Gregory Skovoroda "Every city has a character and law." Institute of Literature named after T.G. Shevchenko of the National Academy of Sciences of Ukraine. F. 86, No. 24, L. 80.

5. The first page of the handwritten dialogue by G. Skovoroda "Narcissus". Kiev, Institute of Literature named after T.G. Shevchenko of the National Academy of Sciences of Ukraine. F. 86, No. 9, L. 67. 
6. The handwritten text of a letter by Gregory Skovoroda to Y. Provitsky (DM RSL. F. 32, 16. 21. L. 1).

7. A watch which belonged to Gregory Skovoroda. The National Literary and Memorial Museum of G.S. Skovoroda.

8. Bust at the burial place of Gregory Skovoroda in the village of Skovorodinovka. Sculptor I. Kavaleridze. 1972.

9. Monument to Gregory Skovoroda in Kiev. Sculptor I. Kavaleridze, architect V. Gnezdilov. 1977.

10. A plaque from the burial place of Gregory Skovoroda. The National Literary and Memorial Museum of G.S. Skovoroda. 